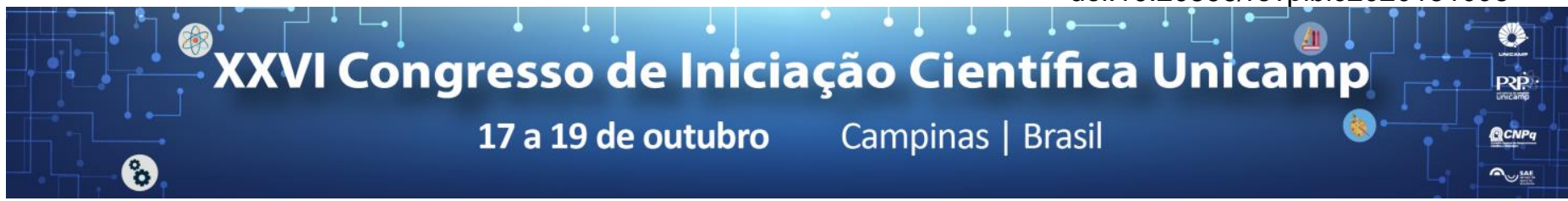

\title{
O Papel do Brasil na Constituição e no Funcionamento Inicial do Banco do Sul e do Banco dos BRICS
}

\section{Nicole Mourad Pereira*, André Martins Biancarelli}

\section{Resumo}

Em um contexto de fortes assimetrias econômicas internacionais, os países em desenvolvimento encontram na cooperação financeira mecanismos de enfrentamento das dificuldades advindas do fenômeno da globalização. Os Bancos de Desenvolvimento representam uma das formas de cooperação, atuando de forma adaptada às necessidades de convergência econômica e infraestrutura de determinadas regiões econômicas. A América do Sul é a região econômica abrangida pelo Banco do Sul, enquanto que o Banco dos BRICS (ou Novo Banco de Desenvolvimento) tem o caráter de ser inter-regional, permeando as regiões econômicas dos países membros (Brasil, Rússia, Índia, China e África do Sul).

\section{Palavras-chave:}

América do Sul e BRICS, Banco de Desenvolvimento, Globalização Financeira

\section{Introdução}

- Contexto de assimetria econômica: Centro e Periferia

- Papel de um Banco de Desenvolvimento

- Banco do Sul (ata fundacional de Dez/2007)

- Banco dos BRICS (cúpula de Jul/2014)

Objetivo: Caracterizar a atuação do Brasil no processo de criação e de início de funcionamento de dois Bancos de Desenvolvimento Regionais - o Banco do Sul e o Banco do BRICS

\section{Cronologia:}

$\begin{array}{ll}\circ & 2006-2010 \text { (Governo Lula) } \\ \circ & 2011-2014 \text { (Governo Dilma) } \\ \circ & 2015-2016 \text { (Governo Temer) }\end{array}$

\section{Resultados e Discussão}

Brasil e o Banco do Sul:

Governo Lula

- Nova Arquitetura Regional e Financeira ("onda rosa")

- Declaração de Quito (2007)

- Consolidação da UNASUL (2008)

Governo Dilma

- Início das operações formais da UNASUL (2011)

- Política externa do Multilateralismo

Governo Temer

- Brasil ainda não ratificou o Convênio do BS

- UNASUL paralisada

Brasil e o Banco dos BRICS:

Governo Lula

- Fortalecimento relação Sul-Sul

- Formalização dos BRICS (2009)

- PEB "altiva e ativa" do Celso Amorim

Governo Dilma

- Multilateralismo

- BRICS usado como bandeira do Governo

- Formalização do NBD (2014)

- Brasil com a vice-presidência do NBD

Governo Temer

○ Início dos empréstimos e projetos (2016)
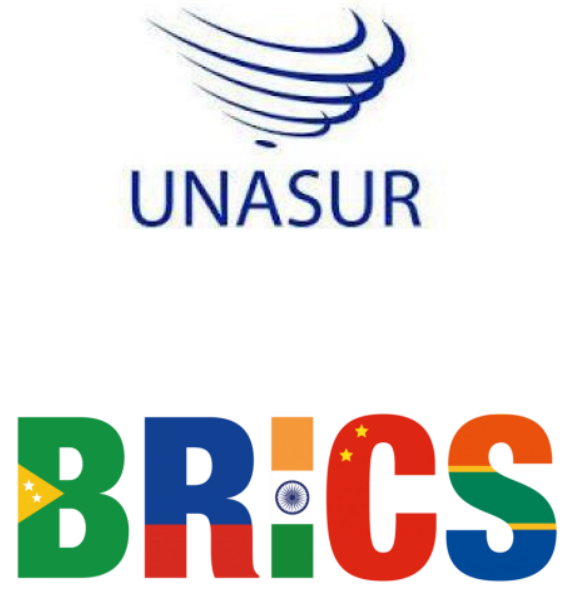

Resultados:

\section{Conclusões}

- Lula fortalece os laços com a América do Sul

- Dilma arrefece a relação com os vizinhos e foca nos BRICS

- Temer abandona a UNASUL e utiliza-se da imagem dos BRICS

\section{Agradecimentos}

Agradeço ao meu orientador pela oportunidade de desenvolver essa pesquisa, ao meu Instituto e ao meu centro de estudos, o CECON.

Essa pesquisa é financiada pela FAPESP.

ALVES, Elia Elisa Cia; BIANCARELLI, André Martins. Cooperação financeira e distintos projetos regionais: o caso do Banco do Sul. Nova Economia, v. 25, n. 3, p. 717-736, 2015

BIANCARELLI, André. Financial cooperation within the context of South American integration: Current balance and future challenges. Interamerican Development Bank Integration \& Trade Journal, v. 33, n. 15, p. 17-26, 2011.

GARCIA, Marco Aurélio. "O lugar do Brasil no mundo: a política externa em um momento de transição." Brasil, entre o passado e o futuro. São Paulo: Boitempo, Fundação Perseu Abramo (2010): 153-176.

MEDEIROS, Carlos Aguiar de. Modelos Alternativos para La integracion sudamericana. Genebra: Monografia de la Red del Instituto Virtual de la UNCTAD, 2010. 